\title{
Monilukutaidot paikallisissa opetussuunnitelmissa
}

\author{
Lauri Palsa \\ Lapin yliopisto \\ lpalsa@ulapland.fi \\ Pekka Mertala \\ Oulun yliopisto \\ pekka-oskari.mertala@oulu.fi \\ https://orcid.org/0000-0002-3835-0220
}

Teknologinen kehitys ja medioituminen ovat tuoneet uusia mahdollisuuksia tiedon välittämiseen ja vuorovaikutukseen. Opetushallitus on reagoinut tähän globaaliin kehityskulkuun sisällyttämällä perusopetuksen opetussuunnitelman perusteisiin monilukutaidoksi nimetyn laaja-alaisen osaamisalueen (Opetushallitus, 2014). Perusteissa monilukutaitoa lähestytään tarpeen, kompetenssin ja käytänteiden näkökulmista. Tarve perustellaan sillä, että oppilaat tarvitsevat monilukutaitoa osatakseen tulkita maailmaa ympärillään ja monilukutaito tukee kriittisen ajattelun ja oppimisen taitojen kehittymistä. Monilukutaito perustuu laaja-alaiseen käsitykseen tekstistä, ja kompetenssina se tarkoittaa esimerkiksi kirjoitetussa, puhutussa, painetussa, audiovisuaalisessa tai digitaalisessa muodossa olevien tekstien tuottamisen, lukemisen ja arvioinnin taitoja. Monilukutaidon kehittymistä tukevat käytänteiksi nimetään rikasta tekstiympäristöä sekä yksin ja yhdessä tapahtuvaa tekstien tuottamista ja tulkitsemista. Oppilaiden monilukutaitoa tulee edistää kaikissa oppiaineissa sekä yhteistyössä koulun ulkopuolisten toimijoiden kanssa. (Opetushallitus, 2014.) 
Monilukutaito on suomalaisessa kontekstissa uusi käsite (Kupiainen, 2016) eikä uusien käsitteiden sisäistäminen ja pedagoginen juurruttaminen ole koskaan itsestäänselvyys. Monilukutaidon kohdalla tämä näkyy muun muassa käsitteen epäjohdonmukaisessa käytössä niin opetussuunnitelmateksteissä kuin akateemisissa ja ammatillisissa julkaisuissa (Mertala, 2018; Palsa \& Ruokamo, 2015). Kuitenkaan sitä, miten koulutuksen järjestäjät käsitteen hahmottavat, ei ole toistaiseksi tutkittu. Tämä laadullinen tutkimus vastaa tähän tarpeeseen tarkastelemalla sitä, miten monilukutaito on määritelty paikallisissa opetussuunnitelmissa. Koska opetussuunnitelman perusteisiin on kirjattu vaade paikalliseen tarkentamiseen (Opetushallitus, 2014) fokuksemme on erityisesti siinä, miten monilukutaito on kontekstualisoitu huomioimaan paikalliset erityispiirteet, tarpeet ja resurssit. Tutkimuksessa haemme vastauksia seuraaviin kysymyksiin:

1. Miten monilukutaidon tarve määritellään paikallisissa opetussuunnitelmissa?

2. Miten monilukutaito (kompetenssina) määritellään paikallisissa opetussuunnitelmissa?

3. Millaisin käytännöin monilukutaitoa määritellään tuettavan paikallisissa opetussuunnitelmissa?

\section{Aineisto ja analyysi}

219 suomenkielisen paikallisen opetussuunnitelman laaja-alainen osaaminen -luvun monilukutaitomääritelmät analysoitiin laadullisen sisällönanalyysin (Hsieh \& Shannon, 2005) sisällön erittelyn (Jyrhämä, 2004) menetelmin. Analyysiprosessia on avattu tarkemmin taulukkoon 1.

\section{Tulokset}

Tutkimuksen tulokset osoittavat, että kontekstualisointi on harvinaista, sillä vain 28 prosentissa $(n=62)$ opetussuunnitelmista monilukutaito oli kontekstualisoitu vähintään yhdellä kolmesta tasosta (ks. Kuva 1).

Kontekstualisoinnin perusteellisuus vaihteli paikallisissa opetussuunnitelmissa yksittäisistä sanoista kappaleisiin. Kontekstualisointeja tehtiin paikallisin painotuksin sekä määritelmällisin lisäyksin, esimerkiksi tarkentamalla tiettyjä osa-alueita. Paikallisten opetussuunnitelmien painotuksilla pyrittiin myös tukemaan opetuksen suunnittelua ja ohjaamaan opetuksellista käytäntöä.

Paikalliset kontekstualisoinnit kuvastavat monilukutaitoon liittyvää moninaisuutta. Monilukutaidon tarvetta perusteltiin esimerkiksi pirstaloituneen 


\begin{tabular}{|c|c|c|}
\hline & Tutkimuskysymys & Aineistoesimerkki \\
\hline $\begin{array}{l}\text { Monilukutaidon } \\
\text { tarve }\end{array}$ & $\begin{array}{l}\text { Miten monilukutaidon tarve määritellään } \\
\text { paikallisissa opetussuunnitelmissa? }\end{array}$ & $\begin{array}{l}\text { "Oppilaiden monilukutaidon kehittymistä } \\
\text { ohjataan kohti taitoja, joiden avulla } \\
\text { sirpaleista maailmaa voidaan lähestyä } \\
\left.\text { hallittavina kokonaisuuksina." (OPS }{ }_{57}\right)\end{array}$ \\
\hline $\begin{array}{l}\text { Monilukutaidon } \\
\text { määritelmä }\end{array}$ & $\begin{array}{l}\text { Miten monilukutaito (kompetenssina) } \\
\text { määritellään paikallisissa } \\
\text { opetussuunnitelmissa? }\end{array}$ & $\begin{array}{l}\text { "Kouluissa käsitetään teksti sen laajassa } \\
\text { merkityksessä ja painotetaan erilaisten } \\
\text { tekstien ja tiedon lukutaitoa, kuten } \\
\text { kriittistä lukutaitoa, ympäristön, median, } \\
\text { kuvan ja nonverbaalisen viestinnän } \\
\text { lukutaitoa." (OPS 34) }\end{array}$ \\
\hline $\begin{array}{l}\text { Monilukutaidon } \\
\text { tukeminen } \\
\text { käytännössä }\end{array}$ & $\begin{array}{l}\text { Millaisin käytännöin monilukutaitoa } \\
\text { määritellään tuettavan paikallisissa } \\
\text { opetussuunnitelmissa? }\end{array}$ & $\begin{array}{l}\text { "Hyödynnetään globaalien medioiden } \\
\text { lisäksi paikallisia medioita } \\
\text { monilukutaidon kehittämisessä." (OPS } \\
\text { 27) }\end{array}$ \\
\hline
\end{tabular}

Taulukko 1: Analyyttinen kehys

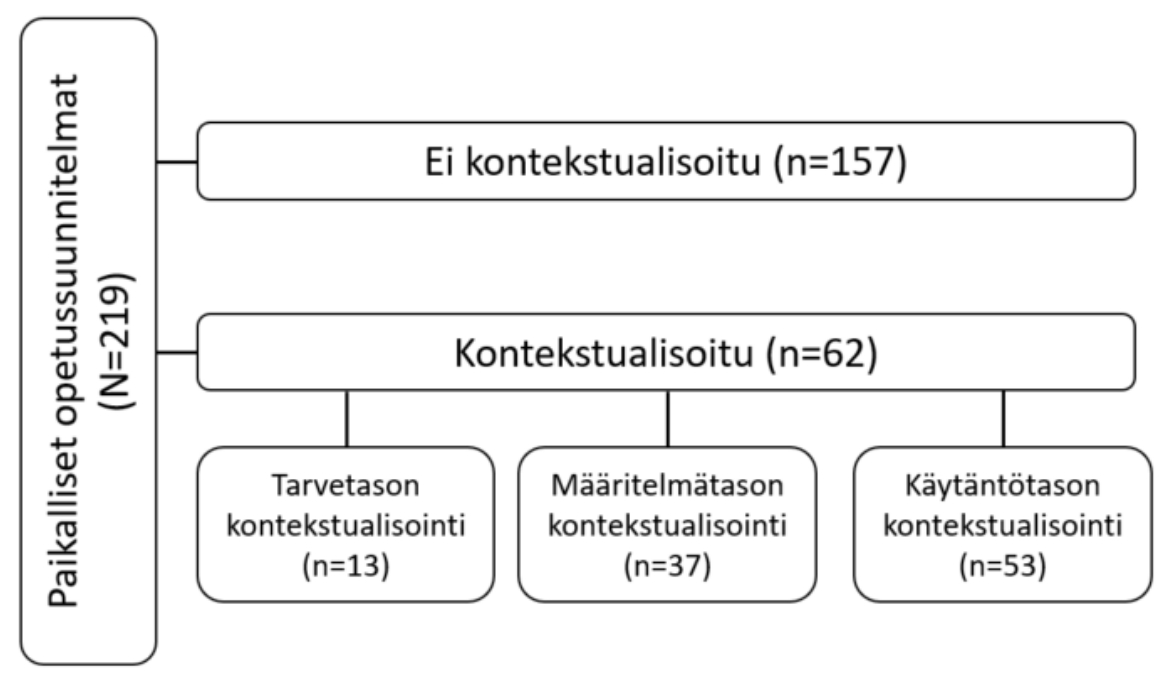

Kuva 1: Kontekstualisoinnin tasot paikallisissa opetussuunnitelmissa 
maailman ymmärtämisellä ja median merkityksellä lasten ja nuorten elämässä. Käsitettä voidaan lähestyä eri näkökulmista ja se voi saada erilaisia muotoja kontekstista riippuen. Yksi esimerkki määritelmän tarkentamisesta on eritellä monilukutaitoon kuuluvia muita lukutaitoja. Monilukutaitoon nähdään analyysin perusteella kuuluvan esimerkiksi medialukutaito, perusluku- ja kirjoitustaidot, kriittinen lukutaito, numeerinen lukutaito, digitaalinen lukutaito ja informaatiolukutaito. Monilukutaitoa voi analyysin perusteella edistää monin eri tavoin, esimerkiksi suunnittelemalla toimintaa erilaisista pedagogisista lähtökohdista, tekemällä yhteistyötä ja hyödyntämällä erilaisia välineitä.

Opetussuunnitelman käsitteitä tarkentamalla voidaan vähentää laajoihin käsitteisiin liittyvää monitulkintaisuutta. Erityisesti tärkeää tämä on laadittaessa paikallisia opetussuunnitelmia, sillä niiden pohjalta tehdään käytännön opetuksen suunnittelua esimerkiksi lukuvuosisuunnitelmien kohdalla. Oppilaiden yhdenvertaisuuden näkökulmasta yhteinen ymmärrys laaja-alaisesta osaamisesta on tärkeää, ei vain eri kuntien välillä mutta myös yksittäisten kuntien sisällä.

\section{Lähteet}

Hsieh, H.-F., \& Shannon, S. E. (2005). Three Approaches to Qualitative Content Analysis. Qualitative Health Research, 15(9), 1277-1288. https://doi .org/10.1177/1049732305276687

Jyrhämä, R. (2004). Sisällön erittelyn mahdollisuuksia: Taulukkolaskentaohjelma analysoinnin apuna. Teoksessa P. Kansanen \& K. Uusikylä (toim.), Opetuksen tutkimuksen monet menetelmät (ss. 223-237). Jyväskylä: PS-kustannus.

Kupiainen, R. (2016). Monilukutaidon pedagogiikka ja sosiaalinen diversiteetti. Teoksessa K. Leino \& O. Kallionpää (toim.), Monilukutaitoa digiaikaan : lukemisen ja kirjoittamisen uudet haasteet ja mahdollisuudet (ss. 23-30). Helsinki: Äidinkielen opettajain liitto.

Mertala, P. (2018). Lost in translation? - Huomioita suomalaisten opetussuunnitelmien monilukutaito-käsitteen tutkimuksellisista ja pedagogisista haasteista. Media \& viestintä, 41(1). http://urn.fi/urn:nbn:fi-fe2018060725477

Opetushallitus. (2014). Perusopetuksen opetussuunitelman perusteet. Helsinki: Opetushallitus. https://www.oph.fi/saadokset_ja_ohjeet/opetussuunnitelmien_ja_tutkintojen_ perusteet/perusopetus

Palsa, L., \& Ruokamo, H. (2015). Behind the concepts of multiliteracies and media literacy in the renewed Finnish core curriculum: A systematic literature review of peer-reviewed research. Seminar.net, 11(2). https://journals.hioa.no/index.php/seminar/article/view/2354 